Nikolina Posarić *

Karolina Kokot **

Marina Klačmer Čalopa ${ }^{* * *}$
JEL Classification M1, M12 Prethodno priopćenje https://doi.org/10.32910/ep.70.2.5

\title{
ANALIZA ZASTUPLJENOSTI ŽENA NA UPRAVLJAČKIM POZICIJAMA U HRVATSKIM PODUZEĆIMA I NJIHOV UTJECAJ NA USPJEŠNOST POSLOVANJA
}

O radu nadzornog odbora i uprave u kontinentalnom modelu korporacijskog upravljanja, odnosno upravnom odboru u američkom modelu, ovisi uspješnost poslovanja poduzeća. Stoga je sastav takvih odbora ključan te se na tu temu provode istraživanja s ciljem utvrđivanja optimalnog sastava. Spolna raznolikost spomenutih odbora u zadnje vrijeme dobiva sve veći značaj, ne samo zbog istraživanja kojima se dokazuje da je članstvo žena u takvim odborima pozitivno za uspješnost poslovanja poduzeća, već i zbog zakonskih zahtjeva, kojima se želi postaviti minimalna granica uz broj žena u takvim odborima. U ovom radu analizira se zastupljenost žena na upravljačkim pozicijama u hrvatskim poduzećima te istražuje utjecaj spolne raznolikosti u upravama $i$ nadzornim odborima na uspješnost poslovanja poduzeća. Provedeno je istraživanje na uzorku od 400 najvećih hrvatskih poduzeća. Rezultati pokazuju mali postotak žena u upravama i nadzornim odborima hrvatskih poduzeća te kako se ne može sa sigurnošću tvrditi da spolna raznolikost u upravama i nadzornim odborima doprinosi uspješno-

${ }^{*}$ N. Posarić, mag. oec., Fakultet organizacije i informatike Sveučilišta u Zagrebu (E-mail: niposari@foi.hr).

${ }^{* *}$ K. Kokot, mag. oec., Fakultet organizacije i informatike Sveučilišta u Zagrebu (E-mail: kkokot@foi.hr).

*** Dr. sc. M. Klačmer Čalopa, izvanredna profesorica, Fakultet organizacije i informatike Sveučilišta u Zagrebu (E-mail: marina.klacmer@foi.hr).

Rad je nagrađen Rektorovom nagradom Sveučilišta u Zagrebu u akademskoj godini 2014./2015. te je prilagođen objavi u časopisu.

Rad je primljen u uredništvo 24.08.2017. godine, a prihvaćen je za objavu 10.09.2018. 
sti poduzeća. Ipak, vidi se utjecaj spolne raznolikosti u nadzornim odborima na uspješnost poduzeća, što bi moglo biti predmet daljnjih istraživanja.

Ključne riječi: upravljačke pozicije, uspješnost poslovanja, nadzorni odbor, uprava, upravni odbor

\section{Uvod}

Posljednjih godina sve se više govori o ravnopravnosti spolova i poticanju uravnotežene zastupljenosti žena i muškaraca u različitim sferama života, od zapošljavanja, napredovanja na radnom mjestu, političkog angažmana, poduzetništva i drugo. Time rasprave na temu uloge i zastupljenosti žena na upravljačkim pozicijama u poduzeću dobivaju na važnosti. Sve su brojnija istraživanja koja pokazuju da su poduzeća kojima upravljaju žene uspješnija od poduzeća kojima upravljaju muškarci (Joy i sur., 2007., McKinsey \& Company, 2007., McElhaney i Mobasseri, 2012., Credit Suisse Research, 2014. i 2016.). Jedan od uočenih razloga su razlike u vještini vođenja i upravljanja, a istraživanja pokazuju da žene posjeduju bolje kompetencije poput preuzimanja inicijative i usmjerenosti na rezultate koje su dugo smatrane isključivo muškim kompetencijama (Zenger i Folkman, 2012.). Na upravljačkim pozicijama žene češće primjenjuju demokratski stil vođenja i upravljanja te razvijaju bolje međuljudske odnose na razini cijele organizacije (Galičić i Ivanković, 2006., Helgesen i Johnson, 2011., Zenger i Folkman, 2012., Pološki Vokić i Bulat, 2013.).

Dostupna strana i domaća znanstvena i stručna literatura obrađuje zastupljenost žena na upravljačkim pozicijama (Davies, 2011., Ružić i Perušić, 2014., Europski institut za ravnopravnost spolova, 2017., Pravobraniteljica za ravnopravnost spolova, 2011., 2014., 2016.) i njihovu ulogu u upravljanju poduzećem. Međutim, još uvijek ima prostora za nova istraživanja koja bi se bavila zastupljenošću i uspješnošću žena u svim aspektima vođenja i upravljanja.

Svrha ovog rada je analiza zastupljenosti žena na pozicijama predsjednice, odnosno članica uprave i nadzornog odbora u promatranim hrvatskim poduzećima te njihov utjecaj na uspješnost poslovanja poduzeća. Autorice daju pregled dosadašnjih znanstvenih spoznaja i istraživanja na temelju dostupne relevantne znanstvene i stručne literature koja obrađuje konceptualni okvir upravljačke strukture poduzeća, karakteristike žena kao menadžera i razlike između načina vođenja i upravljanja. Nakon pregleda dosadašnjih istraživanja, autorice iznose istraživačke hipoteze, metodologiju te rezultate istraživanja. Na kraju rada izneseni su zaključci, uočena ograničenja u istraživanju te implikacije za buduća istraživanja. 
N. POSARIĆ, K. KOKOT, M. KLAČMER ČALOPA: Analiza zastupljenosti žena na upravljačkim pozicijama u hrvatskim... EKONOMSKI PREGLED, 70 (2) 259-275 (2019)

\section{Pregled dosadašnjih istraživanja}

\subsection{Konceptualni okvir upravljačke strukture}

Kao konceptualni okvir upravljačke strukture, literatura i praksa prepoznaju jednorazinski (monistički, angloamerički) model korporacijskog upravljanja te dvorazinski (dualistički, kontinentalni) model korporacijskog upravljanja, koji se razlikuju prema načinu organiziranja funkcija vođenja poslova i nadzora u poduzeću (Tipurić, 2006.). Monistički sustav korporacijskog upravljanja obilježava objedinjenost funkcija vođenja poslova i nadzora kroz upravni odbor (engl. board of directors). Razumijevanje nadzorne funkcije koja je objedinjena s funkcijom vođenja poslova u jednom odboru zahtijeva da se razlikuju izvršni ili unutarnji (executive directors) i neizvršni ili vanjski direktori (non-executive directors) (Maurović i sur., 2009.). Izvršni ili unutarnji direktori su direktori koji rade puno radno vrijeme u poduzeću i posvećeni su dnevnom vođenju poslova poduzeća. S druge strane, neizvršni ili vanjski direktori nisu zaposlenici društva i nisu izravno povezani s poduzećem, već su zaduženi za nadzor poslovanja poduzeća (Gonan Božac, Šumberac, 2009.).

U dualističkom sustavu korporacijskog upravljanja prisutna je podjela funkcija vođenja poslova i nadzora te formiranje dva organa: uprave (engl. management board) i nadzornog odbora (engl. supervisory board), gdje je uprava odgovorna za vođenje poslova i upravljanje društvom, a nadzorni odbor nadzire djelovanje uprave. Za strukturu dualističkog sustava korporacijskog upravljanja karakteristična su jaka prava dioničara, specifičan pravni režim te struktura nadzornog odbora. Kroz izbor menadžera, kontinuirano vrednovanje rada uprave, nadzorni odbor stvara uvjete za uspjeh društva. Nadzorni odbor nadzire rad uprave, ali ne svaku radnju uprave, već samo radnje uprave kojima ona vodi društvo. Isto tako, mora djelovati i preventivno na način da savjetuje upravu i utječe na poslovnu politiku društva čime ostvaruje ulogu vođenja društva (Maurović i sur., 2009.).

Dominantan oblik djelovanja dioničkih društava u Hrvatskoj je dvorazinski model korporacijskog upravljanja, a uloga i povezanost uprave, nadzornog odbora i skupštine definirana je Zakonom o trgovačkim društvima ${ }^{1}$.

${ }^{1}$ (NN 111/93, 34/99, 121/99, 52/00, 118/03, 107/07, 146/08, 137/09, 125/11, 152/11, 111/12, $68 / 13,110 / 15)$. 


\section{2. Žene kao menadžeri i razlike između muškog $i$ ženskog načina vođenja}

Provedena istraživanja pokazuju kako žene koje imaju dovoljno znanja i profesionalnoga iskustva preuzimaju upravljačke pozicije, što se može jedinim dijelom pripisati uputama i pravilnicima s europske i nacionalne razine koji nalažu uravnoteženo zapošljavanje, promjene društvenih stajališta i kvalifikacijskih kriterija, a s druge strane žene u većem postotku imaju visoko obrazovanje i kontinuirano se usavršavaju za određene upravljačke pozicije. Žene u Republici Hrvatskoj predstavljaju većinu visoko obrazovanog stanovništva. Prema podacima Državnog zavoda za statistiku (2016.) u 2015. godini je 60\% studentica u generaciji završilo sveučilišni ili stručni studij. Istraživanje (Pravobraniteljica za ravnopravnost spolova, 2016.) pokazuje kako ipak 25\% muškaraca u upravi ima završen najviši stupanj obrazovanja (doktorat znanosti), dok isti stupanj obrazovanja ima 10\% žena.

Za žene je karakterističan stil interaktivnog vodstva koji uključuje „podjelu informacija i moći, poticanje sudjelovanja te davanje ljudima na znanje da su važni“ (Galičić i Ivanković, 2006., 83.). U pravilu se ženama pripisuje tzv. ženski stil vođenja koji je demokratski, osjećajan, odnosno tzv. „,meki stil““ vođenja. Za razliku od tog stila, autokratski stil je uobičajeniji za muškarce i naziva se tzv. „tvrdim stilom“" vođenja (Pološki Vokić i Bulat, 2013.).

Helgesen i Johnson (2011.) proveli su u SAD-u istraživanje koje je pokazalo kako menadžerice kao kriterij uspješnosti poslovanja uzimaju kvalitetu ljudskih odnosa. Međuljudski odnosi koji su za žene izuzetno važni, imaju sve veću vrijednost u organizacijskoj kulturi. Oni su važan izvor novih inovativnih procesa, timskog rada, postizanja zadovoljstva klijenata, ali i zadržavanja kvalitetnih zaposlenika te prenošenje znanja. Zenger i Folkman (2012.) proveli su istraživanje vezano uz različitost stilova vodstva između žena i muškaraca koje je obuhvatilo 7280 menadžera iz najuspješniji poslovnih organizacija. Menadžeri su ocjenjivani prema 16 kompetencija, kao što su preuzimanje inicijative, motiviranje, razvoj i slično. Rezultati istraživanja pokazali su kako najviše upravljačke pozicije imaju muškarci (64\%) dok se taj udio smanjuje prema nižim razinama menadžmenta. Ujedno, rezultati istraživanja su pokazali kako žene koje imaju niže menadžerske pozicije imaju bolje razvijene vještine vezane uz razvoj zaposlenika, izgradnju odnosa, ali i samorazvoja. U odnosu na menadžere lošije su ocijenjene za razvoj strateške perspektive (Zenger i Folkman, 2012.).

\subsection{Zastupljenost žena na upravljačkim pozicijama}

Stvaranje uravnotežene zastupljenosti između muškaraca i žena na upravljačkim pozicijama postaje sve važnije pitanje društvenih normi. Davies (2011.) je 
istraživanjem provedenim na poduzećima iz burzovnih indeksa Londonske burze FTSE 100 i FTSE 250, dokazao podzastupljenost žena na upravljačkim pozicijama. Udio žena u upravnim odborima poduzeća uključenih u FTSE 100 indeks je iznosio $12,5 \%$, a ako se u obzir uzimaju poduzeća koja ulaze u FTSE 250 indeks, tada udio žena u upravnim odborima iznosi 7,8\% (Davies, 2011.). Istraživanje Europske komisije (2017.) čije rezultate polugodišnje objavljuje Europski institut za ravnopravnost spolova (engl. European Institute for Gender Equality, EIGE), a koje je provedeno u poduzećima koja kotiraju na burzama, pokazalo je kako postotak žena koje se nalaze na poziciji glavnog izvršnog direktora na razini EU-28 iznosi 5,6\%, postotak žena koje se nalaze na poziciji izvršnih direktora iznosi 15,6\%, dok je postotak žena koje se nalaze na poziciji neizvršnih direktora $26,9 \%$. Slika 1. prikazuje zastupljenost žena na upravljačkim pozicijama poduzeća koja kotiraju na burzama među zemljama Europske unije u 2017. godini. Istraživanje uključuje pozicije glavnog izvršnog direktora, izvršnih direktora i neizvršnih direktora. U Francuskoj je najveća zastupljenost žena na upravljačkim pozicijama $(43,4 \%)$, slijedi Švedska $(35,9 \%)$, dok u Hrvatskoj zastupljenost žena na upravljačkim pozicijama iznosi $21,6 \%$, što je u približno sa Španjolskom (22,0\%), Poljskom (20,1\%) i Slovenijom (22,6\%). Najmanju zastupljenost žena bilježe Estonija $(7,4 \%)$ i Malta $(8,4 \%)$.

Slika 1 .

\section{GRAFIČKI PRIKAZ ZASTUPLJENOSTI ŽENA NA UPRAVLJAČKIM POZICIJAMA U ZEMLJAMA EUROPSKE UNIJE}

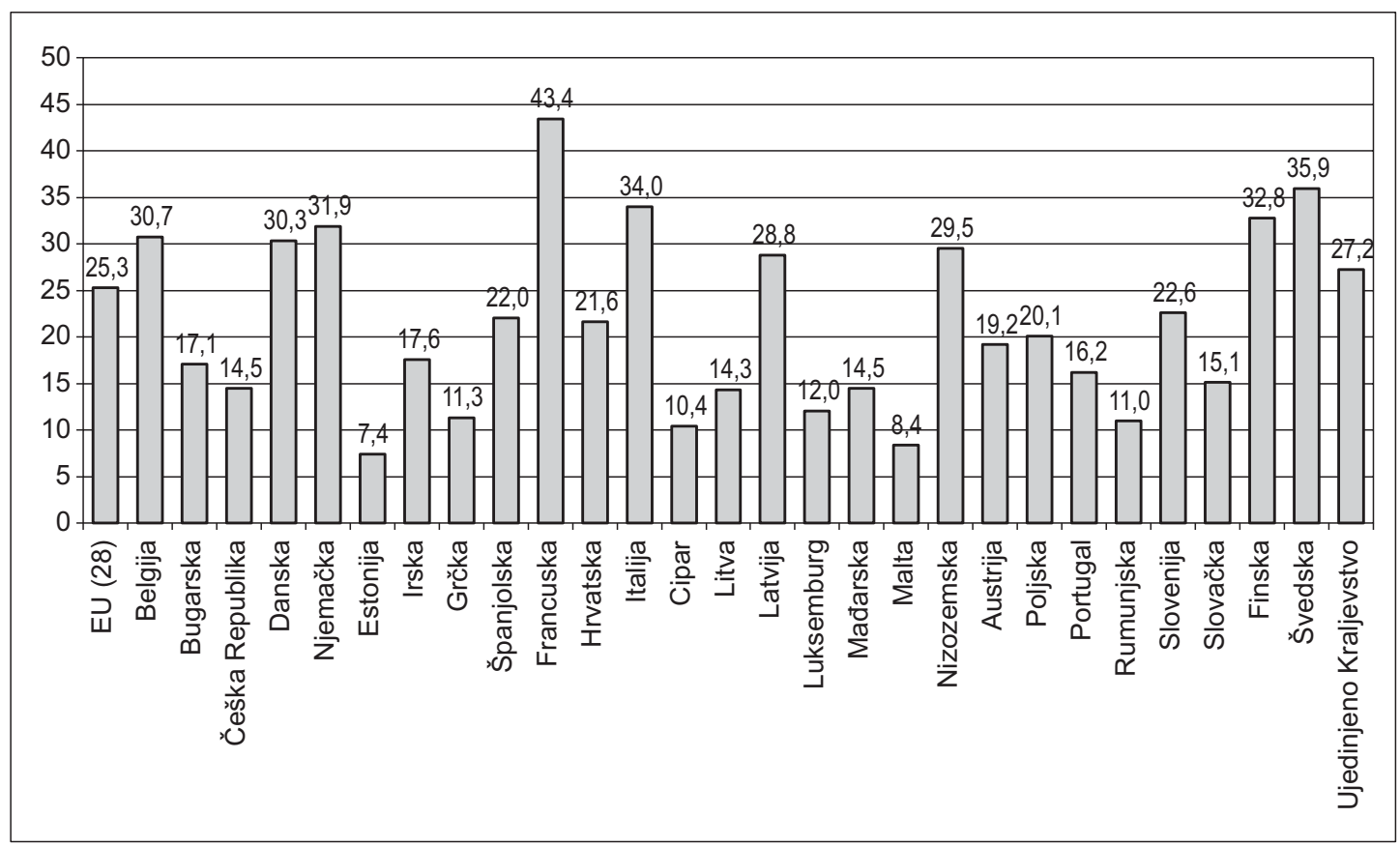

Izvor: izrada autorica prema podacima Europskog instituta za ravnopravnost spolova, 2017. 
Istraživanje provedeno u Hrvatskoj na uzorku 928 članova uprave pokazalo je dominaciju muškog spola (81\%), dok na uzorku 1202 članova nadzornih odbora, muškarci čine $80 \%$. Isto istraživanje pokazalo je kako je samo $9 \%$ žena na poziciji predsjednice uprave što ukazuje na neodgovarajuću zastupljenost žena na upravljačkim pozicijama (Pravobraniteljica za ravnopravnost spolova, 2011.). U istraživanju 2014. godine, u upravi dioničkih društva bilo je 17,32\% žena, a u nadzornom odboru 21,69\%. Istraživanje iz 2014. pokazuje da je postotak žena na poziciji predsjednice uprave $9,43 \%$, dok funkciju predsjednice nadzornog odbora obavlja 14,3\% žena (Pravobraniteljica za ravnopravnost spolova, 2014.). Rezultati istraživanja iz 2016. na uzorku od 21 poduzeća pokazuju da se u upravi nalazi 18,52\% žena i $81,48 \%$ muškaraca, dok je u nadzornom odboru $13,04 \%$ žena i $86,96 \%$ muškaraca (Pravobraniteljica za ravnopravnost spolova, 2016.).

U istraživanju provedenom na 89 europskih poduzeća s tržišnom kapitalizacijom iznad 150 milijuna eura, McKinsey \& Company (2007.) dokazali su kako poduzeća s većom zastupljenošću žena u upravnom odboru imaju veći povrat na uloženi kapital (engl. ROE) u odnosu na prosjek industrije. Rezultati istraživanja pokazali su i bolju dobit prije kamata i poreza (engl. EBIT) koja je iznosila 11,1\% prema 5,8\% koliki je prosjek industrije. Na uzorku od 500 poduzeća sa Fortune ljestvice, Joy i sur. (2007.) proveli su istraživanje koje je pokazalo kako poduzeća gdje je veća zastupljenost žena, 3 ili više žena u upravnim odborima, ostvaruju $42 \%$ veći povrat na prodaju (engl. ROS). Ista poduzeća, ostvaruju 66\% veću stopu povrata na nove investicije (engl. ROIC) te $53 \%$ veći povrat uloženog kapitala (engl. ROE). Credit Suisse Research institut 2014. godine proveo je istraživanje vezano uz spolnu raznolikost te utjecaj na interesno-utjecajne skupine, korporativnu i financijsku uspješnost. Na uzorku od 27.000 menadžera istraživanje je pokazalo kako poduzeća s većom zastupljenošću žena u upravnim odborima imaju veći povrat na kapital (engl. ROE) i to za 28\% (Credit Suisse Research, 2014.). U ponovljenom istraživanju 2016. godine, rezultati pokazuju kako poduzeća s većom zastupljenošću žena u upravnim odborima imaju povrat na kapital (engl. ROE) veći za 19\% (Credit Suisse Research, 2016.).

\section{Istraživačke hipoteze}

Sukladno prepoznatom problemu podzastupljenosti žena na upravljačkim pozicijama u hrvatskim poduzećima, postavljene su tri hipoteze s ciljem provjere zastupljenosti žena na upravljačkim pozicijama te utvrđivanja razlike u uspješnosti poslovanja ovisno o dominaciji muškaraca odnosno žena unutar uprave i nadzornog odbora. 
H1. Na upravljačkim pozicijama 400 najvećih hrvatskih poduzeća udio žena je manji od 40\%? Ovom hipotezom želi se utvrditi udio žena na upravljačkim pozicijama u najvećim hrvatskim poduzećima polazeći od pretpostavke kako je on manji od $40 \%$. Taj je postotak uzet kao granična mjera jer je $40 \%$ žena u odborima poduzeća preporuka Europske komisije, međutim treba naglasiti kako udio od $40 \%$ ne predstavlja granicu za veći utjecaj na uspješnost poslovanja poduzeća, već naputak Europske komisije za poboljšanjem pozicije žena.

H2. Doprinosi li spolna raznolikost među članovima uprave uspješnosti poduzeća? Ovom hipotezom želi se utvrditi jesu li poduzeća gdje je spolna raznolikost u upravi jače izražena uspješnija od prosjeka 400 hrvatskih najvećih poduzeća iz 2013. godine.

H3. Doprinosi li spolna raznolikost među članovima nadzornog odbora uspješnosti poduzeća? Ovom hipotezom želi se utvrditi jesu li poduzeća gdje je spolna raznolikost u nadzornom odboru jače izražena uspješnija od prosjeka 400 hrvatskih najvećih poduzeća iz 2013. godine.

\section{Metodologija istraživanja i znanstveni doprinos}

Istraživanje je provedeno na temelju popisa najvećih hrvatskih poduzeća iz 2013. godine (Privredni vjesnik, 2014.), dok su se podaci o članovima uprave i nadzornog odbora prikupljali pretragom Sudskog registra (https://sudreg.pravosudje.hr/registar/f?p=150:1) i službenih stranica poduzeća.

U istraživanje je bilo uključeno 400 najvećih hrvatskih poduzeća prema kriteriju najvećih ostvarenih prihoda u 2013. godini. Nakon uvida u Sudski registar, neka od poduzeća su zbog različitih razloga izbrisana iz registra te je pročišćeni uzorak sadržavao 383 poduzeća. Istraživanjem su obuhvaćena samo dionička društva i društva s ograničenom odgovornošću. Ukoliko djeluju prema dvorazinskom modelu upravljanja, dionička društva prema Zakonu o trgovačkim društvima ${ }^{2}$ moraju imati nadzorni odbor, a društva s ograničenom odgovornošću samo u određenim slučajevima.

Istraživanje je provedeno na sekundarnim podacima, a autorice su koristile više metoda i tehnika prikupljanja i vrednovanja podataka: analiza i sinteza podataka, deskriptivna statistička analiza i metoda deskripcije, metoda generalizacije, metoda dedukcije, metoda korelacije i t-test koji se koristio za određivanje statističke značajnosti razlike između dva uzorka (Šošić, 2004.), a sve sa svrhom ispitivanja postavljenih hipoteza.

${ }^{2}$ (NN 111/93, 34/99, 121/99, 52/00, 118/03, 107/07, 146/08, 137/09, 125/11, 152/11, 111/12, $68 / 13,110 / 15)$. 


\section{Rezultati istraživanja}

Deskriptivnom statističkom analizom utvrđena su osnovna svojstva promatranog uzorka poduzeća. Od ukupnog broja poduzeća koja su obuhvaćena istraživanjem (383 poduzeća), 117 poduzeća (31\%) ima pravni oblik dioničkog društva, dok njih 266 (69\%) posluje kao društvo s ograničenom odgovornošću. Većina promatranih poduzeća (379 poduzeća) primjenjuje dvorazinski model korporacijskog upravljanja.

Rezultati istraživanja pokazali su da je u 379 promatranih poduzeća 829 članova uprave te 1152 članova nadzornog odbora. Od ukupno 829 članova uprave, 128 je članica što čini tek $15 \%$ žena u upravama promatranih poduzeća. Udio žena u nadzornim odborima iznosi $21 \%$, točnije od 1152 članova nadzornih odbora promatranih poduzeća, 240 je članica. Ova analiza pokazuje da je udio žena na upravljačkim pozicijama 400 najvećih hrvatskih poduzeća manji od 40\%, a 40\% žena u upravnim odborima je preporuka Europske komisije na temelju koje je izrađen i prijedlog direktive u 2013. godini. Time se dolazi do zaključka kako se hipoteza H1 može prihvatiti. Udio muškaraca i žena u upravama i nadzornim odborima hrvatskih poduzeća prikazan je na slici 2.

Slika 2.

\section{GRAFIČKI PRIKAZ UDJELA ŽENA I MUŠKARACA U UPRAVAMA I NADZORNIM ODBORIMA HRVATSKIH PODUZEĆA}

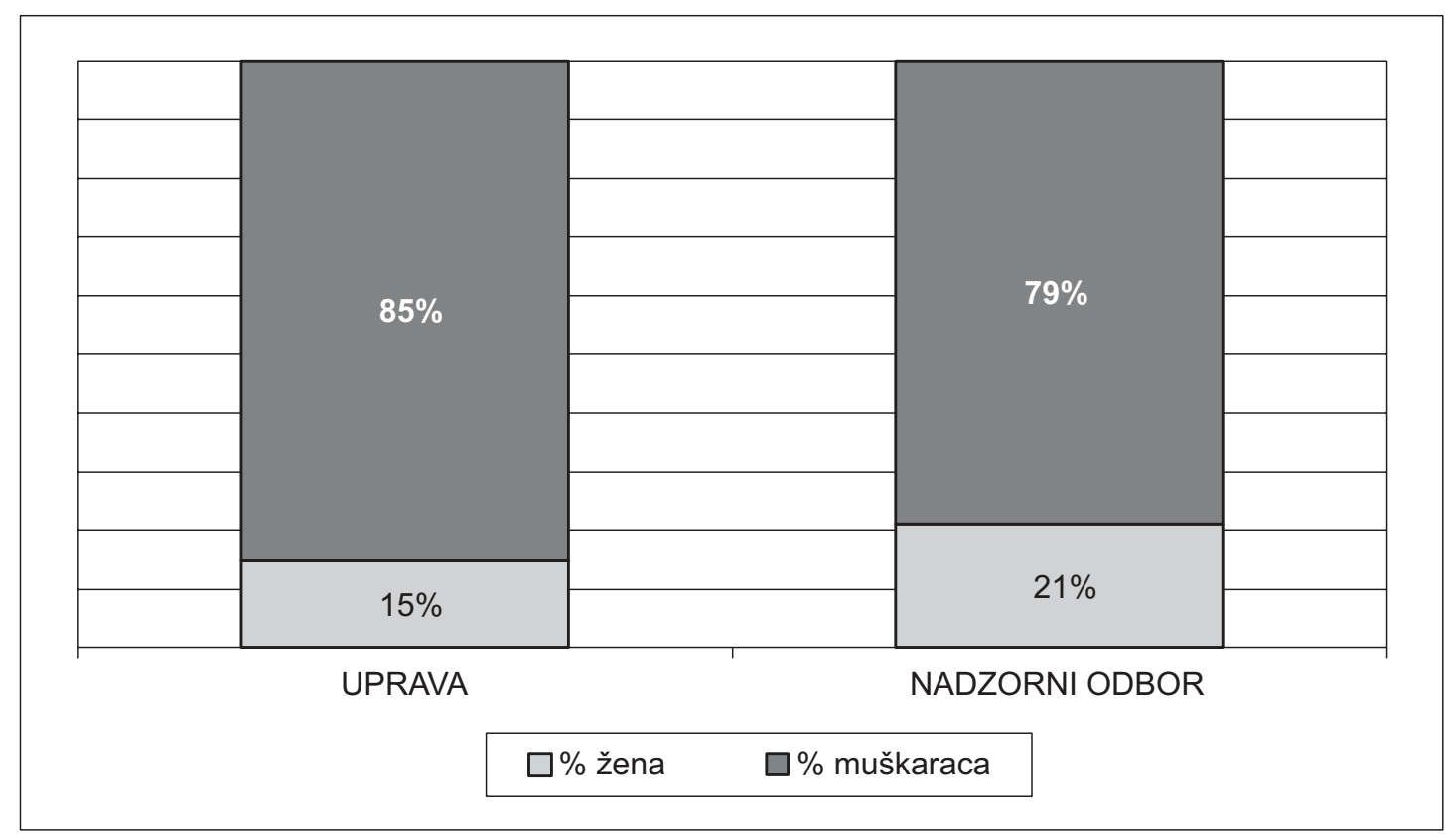

Izvor: izrada autorica 
N. POSARIĆ, K. KOKOT, M. KLAČMER ČALOPA: Analiza zastupljenosti žena na upravljačkim pozicijama u hrvatskim... EKONOMSKI PREGLED, 70 (2) 259-275 (2019)

Dobiveni podaci ukazuju na podzastupljenost žena u upravama i nadzornim odborima hrvatskih poduzeća. U tablici 1. prikazani su rezultati deskriptivne analize sekundarnih podataka iz koje je vidljivo kako je prosječan broj žena u upravama i nadzornim odborima promatranih hrvatskih poduzeća manji od 1.

Tablica 1.

DESKRIPTIVNA ANALIZA BROJA ČLANOVA UPRAVE, BROJA ŽENA U UPRAVAMA, BROJA ČLANOVA NADZORNOG ODBORA I BROJA ŽENA U NADZORNIM ODBORIMA HRVATSKIH PODUZEĆA

\begin{tabular}{|c|c|c|c|c|}
\hline & $\begin{array}{c}\text { Broj } \\
\text { članova } \\
\text { uprave }\end{array}$ & $\begin{array}{c}\text { Broj žena u } \\
\text { upravama }\end{array}$ & $\begin{array}{c}\text { Broj članova } \\
\text { nadzornog } \\
\text { odbora }\end{array}$ & $\begin{array}{c}\text { Broj žena u } \\
\text { nadzornom } \\
\text { odboru }\end{array}$ \\
\hline Prosjek & 2,187335092 & 0,337730871 & 4,571428571 & 0,952380952 \\
\hline Medijan & 2 & 0 & 5 & 1 \\
\hline Mod & 1 & 0 & 3 & 1 \\
\hline Raspon varijacije & 8 & 3 & 9 & 6 \\
\hline Minimalna vrijednost & 1 & 0 & 2 & 0 \\
\hline Maksimalna vrijednost & 9 & 3 & 11 & 6 \\
\hline Suma & 829 & 128 & 1152 & 240 \\
\hline Ukupan broj promatranih poduzeća & 379 & 379 & 252 & 252 \\
\hline
\end{tabular}

Izvor: izrada autorica

Od ukupno promatranih 379 poduzeća, njih 128 (15\%) u upravi ima jednu ili više žena. U tablici 2. je prikazana prosječna dobit nakon oporezivanja svih poduzeća koja su obuhvaćena istraživanjem i ona koja imaju minimalno jednu ženu. Iz tablice 2. je vidljivo kako poduzeća koja imaju barem jednu ženu u upravi imaju veću prosječnu dobit nakon oporezivanja u odnosu na sva poduzeća koja su bila obuhvaćena istraživanjem. 
Tablica 2 .

USPOREDBA PROSJEČNE DOBITI NAKON OPOREZIVANJA PODUZEĆA OBUHVAĆENIH ISTRAŽIVANJEM I PODUZEĆA KOJA IMAJU ŽENU/E U UPRAVI

\begin{tabular}{|l|c|}
\hline & Prosječna dobit nakon oporezivanja \\
\hline Poduzeća obuhvaćena istraživanjem & $37.532 .717,51 \mathrm{kn}$ \\
\hline Poduzeća koja imaju ženu/e u upravi & $45.074 .947,17 \mathrm{kn}$ \\
\hline
\end{tabular}

Izvor: izrada autorica

Od ukupno 252 poduzeća koja imaju nadzorni odbor, njih 158 ili 63\% ima jednu ili više žena u nadzornom odboru. Tablica 3. prikazuje usporedbu prosječne dobiti nakon oporezivanja svih poduzeća koja ima nadzorni odbor s prosječnim prihodima i dobiti nakon oporezivanja onih poduzeća koja imaju barem jednu ženu u nadzornom odboru. Iz tablice 3. je vidljivo kako poduzeća koja imaju barem jednu ženu u nadzornom odboru imaju veću prosječnu dobit nakon oporezivanja u odnosu na poduzeća koja imaju nadzorni odbor i koja su bila obuhvaćena istraživanjem.

Tablica 3 .

USPOREDBA PROSJEČNE DOBITI NAKON OPOREZIVANJA IZMEĐU PODUZEĆA KOJA IMAJU NADZORNI ODBOR I PODUZEĆA KOJA IMAJU ŽENE U NADZORNOM ODBORU

\begin{tabular}{|l|c|}
\hline & Prosječna dobit nakon oporezivanja \\
\hline Poduzeća koja imaju nadzorni odbor & $49.153 .429,37 \mathrm{kn}$ \\
\hline $\begin{array}{l}\text { Poduzeća koja imaju ženu/e u } \\
\text { nadzornom odboru }\end{array}$ & $55.615 .244,30 \mathrm{kn}$ \\
\hline
\end{tabular}

Izvor: izrada autorica

Kako bi se utvrdilo postoji li statistička povezanost između promatranih varijabli, korišten je Pearsonov koeficijent korelacije, a tablica 4. prikazuje dobivene rezultate. $\mathrm{Na}$ temelju dobivenih rezultata može se vidjeti kako, prema Dumičić i sur. (2011.), između promatranih varijabli postoje slabe pozitivne veze. 
N. POSARIĆ, K. KOKOT, M. KLAČMER ČALOPA: Analiza zastupljenosti žena na upravljačkim pozicijama u hrvatskim... EKONOMSKI PREGLED, 70 (2) 259-275 (2019)

Tablica 4.

\section{STATISTIČKE POVEZANOSTI IZMEĐU VARIJABLI DOBIVENE KORELACIJOM}

\begin{tabular}{|l|c|c|}
\hline \multicolumn{1}{|c|}{ Promatrane varijable } & Pearsonov koeficijent & Jačina veze \\
\hline $\begin{array}{l}\text { Broj žena u upravi i dobit } \\
\text { nakon oporezivanja }\end{array}$ & 0,065027 & Slaba pozitivna veza \\
\hline $\begin{array}{l}\text { Broj žena u nadzornom odboru } \\
\text { i dobit nakon oporezivanja }\end{array}$ & 0,078599 & Slaba pozitivna veza \\
\hline
\end{tabular}

Izvor: izrada autorica

Tablica 5. prikazuje razliku između dobiti nakon oporezivanja poduzeća koja imaju članove uprave muškog spola i poduzeća koja imaju članove uprave muškog i ženskog spola. Iz tablice 5. je vidljivo kako poduzeća u kojima postoji spolna raznolikost u upravi imaju veću dobit nakon oporezivanja od onih u kojima su prisutni samo članovi muškog spola u upravi.

Tablica 5.

\section{RAZLIKA IZMEĐU DOBITI NAKON OPOREZIVANJU OVISNO O STRUKTURI UPRAVE PREMA SPOLU}

\begin{tabular}{|c|l|c|c|c|c|}
\hline & \multicolumn{1}{|c|}{ Spol } & N & Mean & $\begin{array}{c}\text { Std. } \\
\text { Deviation }\end{array}$ & $\begin{array}{c}\text { Std. Error } \\
\text { Mean }\end{array}$ \\
\hline \multirow{2}{*}{$\begin{array}{l}\text { Dobit nakon } \\
\text { oporezivanja }\end{array}$} & $\begin{array}{l}\text { 1 (članovi uprave } \\
\text { muškog spola) }\end{array}$ & 272 & 34477345,22 & 94701283,781 & 5742108,763 \\
\cline { 2 - 6 } & $\begin{array}{l}\text { (članovi uprave } \\
\text { muškog i ženskog } \\
\text { spola) }\end{array}$ & 106 & 45072523,58 & $1,499 \mathrm{E} 8$ & 14555268,013 \\
\hline
\end{tabular}

Izvor: izrada autorica

Tablica 6. prikazuje rezultate t-testa. Koeficijent signifikantnosti (Sig.) iznosi 0,244 i veći je od 0.05 , što znači da razlika u dobiti nakon oporezivanja ako su u upravi samo članovi muškog spola i ako su u upravi članovi i muškog i ženskog spola nije statistički značajna. Iako je vidljivo kako je prosjek dobiti nakon oporezivanja veći ukoliko se u upravi nalaze članovi i muškog i ženskog spola, ta razlika nije statistički značajna, pa se hipoteza H2 ne može prihvatiti. Drugim riječima, ne 
može se sa sigurnošću tvrditi da spolna raznolikost u upravi doprinosiuspješnosti poslovanja.

Tablica 6.

\section{REZULTATI T-TESTA}

\begin{tabular}{|c|c|c|c|c|c|c|c|c|c|c|}
\hline & \multicolumn{2}{|c|}{$\begin{array}{c}\text { Levene's } \\
\text { Test for } \\
\text { Equality of } \\
\text { Variances }\end{array}$} & \multicolumn{7}{|c|}{ t-test for Equality of Means } \\
\hline & & \multirow{2}{*}{ F } & \multirow{2}{*}{ Sig. } & \multirow{2}{*}{$\mathrm{t}$} & \multirow{2}{*}{ df } & \multirow{2}{*}{$\begin{array}{c}\text { Sig. } \\
\text { (2-tailed) }\end{array}$} & \multirow{2}{*}{$\begin{array}{c}\text { Mean } \\
\text { Difference }\end{array}$} & \multirow{2}{*}{$\begin{array}{l}\text { Std. Error } \\
\text { Difference }\end{array}$} & \multicolumn{2}{|c|}{$\begin{array}{l}\text { 95\% Confidence Interval of } \\
\text { the Difference }\end{array}$} \\
\hline & & & & & & & & & Lower & Uper \\
\hline \multirow{2}{*}{\begin{tabular}{|c} 
Dobit \\
nakon \\
oporezi- \\
vanja
\end{tabular}} & \begin{tabular}{|l} 
Equal \\
variances \\
assumed
\end{tabular} & 1,363 & 244 &,- 820 & 376 & 413 & $-10595178,364$ & 12921371,362 & $-36002383,386$ & 14812026,657 \\
\hline & \begin{tabular}{|l} 
Equal \\
variances \\
not \\
assumed \\
\end{tabular} & & & - 677 & 138,923 & 499 & $-10595178,364$ & 15646969,035 & $-41532168,535$ & 20341811,807 \\
\hline
\end{tabular}

Izvor: izrada autorica

Tablica 7. prikazuje razliku između dobiti nakon oporezivanja poduzeća koja imaju članove nadzornog odbora muškog spola i poduzeća koja imaju članove nadzornog odbora muškog i ženskog spola. Iz tablice 7. je vidljivo kako poduzeća u kojima postoji spolna raznolikost u nadzornom odboru imaju veću dobit nakon oporezivanja od onih poduzeća u kojima su prisutni samo članovi muškog spola u nadzornom odboru.

\section{Tablica 7.}

\section{RAZLIKA IZMEĐU DOBITI NAKON OPOREZIVANJU OVISNO O STRUKTURI NADZORNOG ODBORA PREMA SPOLU}

\begin{tabular}{|c|l|c|c|c|c|}
\hline & \multicolumn{1}{|c|}{ Spol } & N & Mean & $\begin{array}{c}\text { Std. } \\
\text { Deviation }\end{array}$ & $\begin{array}{c}\text { Std. Error } \\
\text { Mean }\end{array}$ \\
\hline \multirow{2}{*}{$\begin{array}{l}\text { Dobit nakon } \\
\text { oporezivanja }\end{array}$} & $\begin{array}{l}\text { 1 (članovi nadzornog odbora } \\
\text { muškog spola) }\end{array}$ & 220 & 24401440,00 & 68212017,072 & 4598853,253 \\
\cline { 2 - 6 } & $\begin{array}{l}\text { 2(članovi nadzornog odbora } \\
\text { muškog i ženskog spola) }\end{array}$ & 158 & 55615244,30 & $1,533 \mathrm{E} 8$ & 12193779,682 \\
\hline
\end{tabular}

Izvor: izrada autorica 
Tablica 8. prikazuje rezultate t-testa. U ovom slučaju koeficijent signifikantnosti (Sig.) iznosi 0,000 i manji je od 0.05, što znači da razlika u dobiti nakon oporezivanja ako su u nadzornom odboru samo članovi muškog spola i ako su u nadzornom odboru članovi i muškog i ženskog spola jest statistički značajna. Prosjek dobiti nakon oporezivanja u nadzornom odboru u kojem se nalaze članovi i muškog i ženskog spola značajno je veći od prosjeka dobiti u nadzornom odboru gdje se nalaze samo članovi muškog spola. Navedeno znači da spolna raznolikost u nadzornom odboru doprinosi uspješnosti promatranih poduzeća, pa se hipoteza H3 može prihvatiti.

Tablica 8 .

\section{REZULTATI T-TESTA}

\begin{tabular}{|c|c|c|c|c|c|c|c|c|c|c|}
\hline & \multicolumn{2}{|c|}{$\begin{array}{l}\text { Levene's Test } \\
\text { for Equality } \\
\text { of Variances }\end{array}$} & \multicolumn{7}{|c|}{ t-test for Equality of Means } \\
\hline & & \multirow[t]{2}{*}{ F } & \multirow[t]{2}{*}{ Sig. } & \multirow[t]{2}{*}{$\mathrm{t}$} & \multirow[t]{2}{*}{ df } & \multirow{2}{*}{$\begin{array}{c}\text { Sig. } \\
\text { (2-tailed) }\end{array}$} & \multirow{2}{*}{$\begin{array}{c}\text { Mean } \\
\text { Difference }\end{array}$} & \multirow{2}{*}{$\begin{array}{l}\text { Std. Error } \\
\text { Difference }\end{array}$} & \multicolumn{2}{|c|}{$\begin{array}{l}\text { 95\% Confidence Interval of } \\
\text { the Difference }\end{array}$} \\
\hline & & & & & & & & & Lower & Uper \\
\hline \multirow{2}{*}{$\begin{array}{c}\text { Dobit } \\
\text { nakon } \\
\text { opore- } \\
\text { zivanja }\end{array}$} & $\begin{array}{l}\text { Equal } \\
\text { variances } \\
\text { assumed }\end{array}$ & 18,721 & ,000 & $-2,675$ & 376 & , 008 & $-31213804,304$ & 11668094,871 & $-54156700,247$ & $-8270908,361$ \\
\hline & \begin{tabular}{|l} 
Equal \\
variances \\
not \\
assumed
\end{tabular} & & & $-2,395$ & |201,911 & ,018 & $-31213804,304$ & 13032179,947 & $-56910430,036$ & $-5517178,572$ \\
\hline
\end{tabular}

Izvor: izrada autorica

\section{Rasprava i zaključak}

Upravljačka struktura poduzeća, kao i zastupljenost žena i muškaraca na upravljačkim pozicijama u poduzećima, svakako su jak argument za nova istraživanja i utvrđivanja utjecaja žena na uspješnost poslovanja poduzeća. Zbog sve važnijeg društvenog momenta, novija istraživanja veći naglasak stavljaju na brojčani odnos žena i muškaraca u upravama i nadzornim odborima, odnosno upravnim odborima, a više je razloga za to. Prvi razlog jest što postoji veliki broj istraživanja koja su se bavila problematikom zastupljenosti žena u upravnim odborima (Davies, 2011., Ružić i Perušić, 2014., Europski institut za ravnopravnost spolova, 
2017., Pravobraniteljica za ravnopravnost spolova, 2011., 2014., 2016.). Neka istraživanja uspjela su pokazati kako je spolna raznolikost u upravnim odborima (jednorazinski model korporacijskog upravljanja) povezana s uspješnošću poslovanja poduzeća (Joy i sur., 2007., McKinsey \& Company, 2007., Credit Suisse Research, 2014. i 2016.), što govori o važnosti promatranja spolne raznolikosti. Drugi razlog su razlike između muškog i ženskog načina vođenja i upravljanja. Smatra se kako su žene sklonije primjenjivati ,meki“, demokratski stil vođenja koji ima uporište u timskom radu i dobrim odnosima sa suradnicima, dok je za muškarce karakteristična primjena autokratskog stila vođenja (Galičić i Ivanković, 2006., Helgesen i Johnson, 2011., Zenger i Folkman, 2012., Pološki Vokić i Bulat, 2013.).

Provedeno istraživanje i rezultati istraživanja ukazuju na podzastupljenost žena u upravama i nadzornim odborima hrvatskih poduzeća, ali i da se ne može sa sigurnošću tvrditi kako spolna raznolikost doprinosi uspješnosti poduzeća. Ovo istraživanje ima znanstveni i društveni doprinos jer se još uvijek nedovoljno istraživanja bavi ovom tematikom.

Provedeno istraživanje ima nekoliko ograničenja koja je potrebno istaknuti. Jedno od ograničenja jest ograničeni broj promatranih poduzeća, odnosno u istraživanje nisu bila uključena sva poduzeća sa područja Hrvatske, već nešto manje od 400 najvećih. Jedno od ograničenja proizlazi iz nemogućnosti usporedbe podataka dobivenih u prethodnim istraživanjima provedenima u svijetu, zbog razlika između dva modela korporacijskog upravljanja. Ograničenje koje se mora spomenuti jest i ono vezano uz odabir statističke metode korelacije između samo dviju varijabli, a na uspješnost poslovanja poduzeća utječe više faktora, pa je svakako preporuka provesti složenije statističke analize.

Sukladno spomenutim ograničenjima, implikacije za buduća istraživanja odnose se na proširenje obuhvata istraživanja na veći broj promatranih poduzeća te analizu prema sektorima djelatnosti. Kao kriterij za određivanje uspješnosti poslovanja mogli bi se uzeti financijski pokazatelji kao što su: povrat uloženog kapitala, povrat na prodaju i dr. (Joy i sur., 2007., McKinsey \& Company, 2007., Credit Suisse Research, 2014. i 2016.). Buduća istraživanja mogla bi se oslanjati i na nefinancijske pokazatelje čija primjena utječe na kvalitetu korporacijskog upravljanja i transparentnost poslovanja. Promatrajući u širem kontekstu, spolna raznolikost u odborima mogla bi se povezati s korporativnom održivošću, kao u istraživanju koji su proveli McElhaney i Mobasseri (2012.), a u kojem je uočena korelacija između broja žena u upravnim odborima i uspješnosti poslovanja, pa su tako poduzeća $\mathrm{s}$ više žena proaktivno ulagala u obnovljive izvore energije, poticala uspješnost zaposlenika i stručno usavršavanje, proaktivno upravljala ljudskim potencijalom i imala jasnije definirane strukture upravljanja. 
N. POSARIĆ, K. KOKOT, M. KLAČMER ČALOPA: Analiza zastupljenosti žena na upravljačkim pozicijama u hrvatskim... EKONOMSKI PREGLED, 70 (2) 259-275 (2019)

\section{Literatura:}

Credit Suisse Research (2014.). "The CS Gender 3000: Women in Senior Management". Dostupno na http://30percentclub.org/wp-content/uploads/ 2014/10/2014-09-23_Research_Institute_Women_in_Business.pdf [5.2.2015.]

Credit Suisse Research (2016.). "The CS Gender 3000: The Reward for Change". Dostupno na https://glg.it/assets/docs/csri-gender-3000.pdf [21.8.2017.]

Davies E.M. (2011.) "Women on boards". Dostupno na https://www.gov.uk/government/uploads/system/uploads/attachment_data/file/31480/11-745-women-on-boards.pdf [20.4.2015.]

Dumičić, K. i suradnici (2011.). Poslovna statistika. Zagreb: ELEMENT.

Europska komisija (2013.). Dostupno na http://europa.eu/rapid/press-release_IP13-943_hr.htm [21.8.2017.]

Europski institut za ravnopravnost spolova (2017.). Dostupno na http://eige.europa. eu/gender-statistics/dgs/indicator/wmidm_bus_bus__wmid_comp_compex [10.7.2017.]

Europski institut za ravnopravnost spolova (2017.). Dostupno na http://eige.europa. eu/gender-statistics/dgs/indicator/wmidm_bus_bus__wmid_comp_compex/ bar/metadata [29.1.2018.]

Galičić V., Ivanović Z. (2006.). “Žene menadžeri u hrvatskom hotelijerstvu". Tourism and Hospitality Management, Vol. 12, No. 1, pp. 79-88.

Gonan Božac M., Šumberac V. (2009.). "Introducing single board system at joint stock companies merger - justification of its introduction and development of economic practice in the Republic of Croatia". Ekonomska istraživanja, Vol.22, No. 1., pp. 9-32.

Helgesen S., Johnson J. (2011.). Žensko viđenje - Prava moć zaposlenih žena. Lekenik: Ostvarenje.

Joy L., Carter N.M., Wagener H.M., Narayanan S. (2007.). “The Bottom Line: Corporate performance and women's representation on boards". Dostupno na http://www.catalyst.org/system/files/The_Bottom_Line_Corporate_Performance_and_Womens_Representation_on_Boards.pdf [23.2.2015.]

Maurović Lj., Gonan Božac M., Grgorinić S. (2009.). "Monistički ustroj tijela dioničkog društva - hrvatska praksa". Ekonomska istraživanja, Vol.22.

McElhaney K., Mobasseri S. (2012.) "Women Create A Sustainable Future". Dostupno na http://responsiblebusiness.haas.berkeley.edu/Women_Create_ Sustainable_Value_FINAL_10_2012.pdf [6.2.2015.] 
McKinsey \& Company (2007.). "Women Matter: Gender diversity, a corporate performance driver". Dostupno na http://www.mckinsey.com/features/women_matter [6.2.2015.]

Pološki Vokić N., Bulat I. (2013.) "Što žene lideri unose u politiku - psihološka i radna obilježja, stil vođenja, interesi i perspektive", Serija članaka u nastajanju - C̆lanak broj 13-01.. Dostupno na http://web.efzg.hr/RePEc/pdf/ Clanak\%2013-01.pdf [24.2.2015.]

Pravobraniteljica za ravnopravnost spolova (2011.). "Istraživanje o zastupljenosti žena i muškaraca na rukovodećim i upravljačkim pozicijama u poslovnim subjektima u RH". Dostupno na http://www.prs.hr/attachments/article/178/ Istra\%C5\%BEivanje\%20o\%20zastupljenosti\%20\%C5\%BEena\%20i\%20 mu\% C5\%A1karaca\%20na\%20rukovode\%C4\%87im\%20pozicijama\%20 u\%20poslovnim\%20subjektima\%20RH.pdf [5.2.2015.]

Pravobraniteljica za ravnopravnost spolova (2014.). "Priopćenje za medije - Istraživanje o poziciji žena na upravljačkim funkcijama - Napredovanje samo do „staklenog stropa“. Dostupno na http://www.google.hr/url?sa=t\&rct=j\&q= $\&$ esrc $=$ s $\&$ source $=$ web $\& \mathrm{~cd}=1 \&$ ved $=0 \mathrm{CBsQFjAA} \& u r l=\mathrm{http} \% 3 \mathrm{~A} \% 2 \mathrm{~F} \% 2 \mathrm{Fw}$ ww.prs.hr\%2Fattachments\%2Farticle\%2F1039\%2FPriopcenje \%2520Staklen i\%2520strop\%2520nad\%2520poslovnim\%2520zenama\%2520u\%2520Hrvat skoj_final.doc\&ei=VmzWVOmsLYXraMC-gsAJ\&usg=AFQjCNFlfsdANI8 dZcqD9TmBr6KyaYWbXA [5.2.2015.]

Pravobraniteljica za ravnopravnost spolova (2016.). Istraživanje o zastupljenosti žena i muškaraca na upravljačkim pozicijama u poslovnim subjektima u Republici Hrvatskoj, Top 100, Zagreb. Dostupno na http://rec.prs.hr/wp-content/ uploads/2016/12/PRSRH_Izvjesce_muskarci-zene100_web.pdf [10.4.2018.]

Privredni vjesnik (2014.). Dostupno na https://www.400naj.com/ [10.1.2015.]

Ružić, V., Perušić, M. (2014.). "Položaj žena u menadžmentu - novi trendovi u fenomenu staklenog stropa", Praktični menadžment, Vol. V., br. 1., str. 98-107.

Statistički ljetopis (2016.). Državni zavod za statistiku.

Šošić, I. (2004.). Primijenjena statistika. Zagreb: Školska knjiga.

Tipurić, D. i suradnici (2006.). Korporativno upravljanje. Zagreb: Sinergija.

Zenger J., Folkman J. (2012.). "A Study in Leadership, Women do it Better than Men" - Dostupno na http://www.zfco.com/media/articles/ZFCo. WP.WomenBetterThanMen.033012.pdf [8.2.2015.] 
N. POSARIĆ, K. KOKOT, M. KLAČMER ČALOPA: Analiza zastupljenosti žena na upravljačkim pozicijama u hrvatskim... EKONOMSKI PREGLED, 70 (2) 259-275 (2019)

\title{
ANALYSIS OF REPRESENTATION OF WOMEN IN MANAGEMENT POSITIONS IN CROATIAN COMPANIES AND THEIR IMPACT ON BUSINESS PERFORMANCE
}

\begin{abstract}
Summary
The success of the company's business depends on the work of the Supervisory Board and the Management Board in the continental model of corporate management, and Management Board in the American model. Therefore, the stuff of such boards is essential, and various studies are being conducted on this subject in order to find out their optimal line-up. Sexual diversity of the mentioned boards is getting more and more significant, not only because of research which proves that participation of women in such boards has a positive impact on the success of the companies' business performance, but also due to legal requirements, which aim to limit the minimum number of women in such boards. In this paper, we analyze the participation of women in managerial positions in Croatian companies and we research the impact of sexual diversity of the Management Board and the Supervisory Board on the success of the companies' business performance. Empirical study was conducted on a sample of the 400 largest Croatian companies. The results show that there are a small percentage of women in the Management Board and the Supervisory Board and it cannot be considered that sexual diversity of the mentioned boards contributes to the company's success. However, the impact of sexual diversity of Supervisory Board on the company's success can be seen and that could be subject to the further research.
\end{abstract}

Key words: management positions, success of business performance, Supervisory Board, Management, Management Board 